\title{
STRATEGI RESILIENSI PERSONAL BAGI PEKERJA
}

\author{
Yulia Sholichatun \\ Fakultas Psikologi \\ Universitas Islam Negeri (UIN) Maulana Malik Ibrahim Malang \\ Jl. Gajayana 50 Malang Telp. 0341-558916
}

\begin{abstract}
Abstrak - Bekerja merupakan sebuah aktivitas yang yang sangat penting bagi peningkatan kesejahteraan individu.Bekerja di sisi lain juga merupakan salah satu sumber tekanan hidup yang cukup penting, yang dapat mengancam kesejahteraan individu. Setiap profesi memiliki tantangan masing-masing yang berbeda dengan profesi lain.Tidak jauh berbeda dengan para guru, para dosen perguruan tinggi juga dihadapkan pada sejumlah persoalan kesehatan mental. Resiliensi dalam kehidupan kerja merupakan hal yang bisa untuk terus diusahakan. Tidak hanya berfokus pada kekuatan-kekuatan internal individu tetapi optimalisasi peran eksternal terutama kepemimpinan dan jaringan dukungan sosial dari rekan sekerja menjadi aspek-aspek penting. Bertolak pada persoalan di atas, tulisan ini dituangkan untuk mengeksplorasi konsep resiliensi sebagai sebuah strategi untuk merespon tekanan-tekanan kerja dengan harapan individu mampu meningkatkan kesejahteraan hidupnya.
\end{abstract}

Kata Kunci : Strategi Resiliensi Personal, Pekerja

PSIKOISLAMIKA. Jurnal Psikologi Islam (JPI) copyright @ 2014 Laboratorium Penelitian, Kajian Psikologi Islam dan Penerbitan. Volume 11. Nomor 1, Tahun 2014

\section{PENDAHULUAN}

Bekerja merupakan sebuah aktivitas yang yang sangat penting bagi peningkatan kesejahteraan individu. Sebuah penelitian menemukan bukti bahwa kepuasan hidup lebih tinggi pada mereka yang bekerja daripada yang tidak bekerja (Warr, 1999 dalam Sivanathan, et al, 2004). Bekerja tidak hanya berkaitan dengan pemenuhan kebutuhankebutuhan hidup tetapi juga rasa keberhargaan diri, kebermaknaan diri bagi keluarga dan masyarakat, serta sebuah aktivitas yang menandakan tingkat kematangan seseorang.

Bekerja di sisi lain juga merupakan salah satu sumber tekanan hidup yang cukup penting, yang dapat mengancam kesejahteraan individu. Setiap profesi memiliki tantangan masing-masing yang berbeda dengan profesi lain. Misalnya pada profesi perawat ditemukan tekanan-tekanan yang berhubungan dengan persoalan manajemen kerja, bullying, keamanan kerja serta burn-out (Cline, et al, 2003; McVicar, 2003). Hasil penelitian tentang sumber stres pada guru sekolah menengah di sisi lain menunjukkan adanya faktor-faktor pemicu seperti tingginya beban kerja, hubungan interpersonal, kondisi lingkungan kerja yang tidak nyaman, kelelahan emosi, depersonalisasi serta tuntutan prestasi kerja (Yahaya, Jaalam \& Yahaya, 2009).

Tidak jauh berbeda dengan para guru, para dosen perguruan tinggi juga dihadapkan pada sejumlah persoalan kesehatan mental. Sebuah hasil penelitian di Inggris menunjukkan lebih dari separuh dosen yang bekerja di universitas-universitas di Inggris berada pada ambang kecemasan dan depresi, sementara seperempatnya telah menderita penyakit yang merupakan akibat dari stres yang mereka alami pada 12 bulan sebelumnya (Association of University Teachers, 2000 dalam Sasongko, 2013). Hal tersebut mendukung temuan Economic and Social Research Council, bahwa profesi dosen perguruan tinggi merupakan salah satu dari profesi yang masuk dalam Job Misery Index (dalam Sasongko, 2013). Temuan penelitian di Australia menguatkan pula kenyataan bahwa tingginya tingkat stres yang dialami oleh para dosen di perguruan tinggi menunjukkan peningkatan dramatis dalam satu dekade terakhir. 
Kondisi tersebut telah menyumbangkan munculnya sebuah penyakit sebagai akibat dari stres yang mereka alami (Times Higher Education Supplement, 2003 dalam Sasongko, 2013).

Bertolak pada persoalan di atas, tulisan ini dituangkan untuk mengeksplorasi konsep resiliensi sebagai sebuah strategi untuk merespon tekanantekanan kerja dengan harapan individu mampu meningkatkan kesejahteraan hidupnya.

\section{KONSEP RESILIENSI}

Paradigma psikologi positif telah menempatkan perhatian-perhatian penelitian psikologi dalam aspekaspek yang menjadi kekuatan manusia dibanding kelememahan mereka. salah satu konsep yang banyak dijadikan objek kajian psikologi adalah resiliensi sebagai salah satu faktor penting kesejahteraan dan kebahagiaan individu. Resiliensi dalam sudut paandang sejarah memiliki dua diskursus yakni resiliensi fisiologis dan resiliensi psikologis (Tusaie \& Dyer, 2004).Secara fisiologis manusia memiliki mekanisme homeostatis untuk mengembangkan resiliensi saat menghadapi tekanan kehidupan (Rabkin, et al, 2003). Resiliensi psikologis di sisi lain didefinisikan sebagai kapasitas untuk terus bergerak dalam cara yang positif setelah mengalami kejadian negatif, traumatik maupun kejadian-kejadian stres (Tugade \& Frederickson, 2004).

Resiliensi kadang didefinisikan terkait dengan sekumpulan sifat, kualitas atau karakteristik. Giordano (1997) misalnya mendata sejumlah kualitas yang terkait dengan resiliensi seperti resourcefulness, percaya diri, memiliki rasa ingin tahu yang besar, disiplin diri dan fleksibilitas disamping stamina emosi serta kemampuan penyelesaian masalah.Sejalan dengan Giordano, Jacelon (1997) menegaskan bahwa individu yang resilien adalah yang memiliki kecakapan/kecerdasan serta sense of self yang kuat.Tugade \& Frederickson (2004) menggambarkan sebuah metaphor resiliensi individu dengan elastisitas dan kelenturan pada baja.Mereka menyoroti perbedaan antara baja yang rapuh dan lentur dengan menyerupakan sifat-sifat baja yang lentur tersebut dengan kualitas atau karakteristik psikologis individu yang menjadikan mereka kuat dalam menghadapi ketegangan dan kesulitan.

Resiliensi diposisikan tak terpisahkan dengan adversity atau kesulitan. Kemampuan resiliensi seseorang akan terlihat setelah ia mengalami kesulitan-kesulitan. Coleman dan Ganong (2001) mendefinisikan resiliensi sebagai proses dinamis yang mencakup adaptasi positif dalam menghadapi kesulitan, sedangkan Rutter (1999) secara lebih luas mendefinisikan resiliensi sebagai fenomena untuk mengatasi stres dan tekanan. Definisi resiliensi dalam tulisan ini merangkum dari kedua definisi tersebut, yakni sebagai sebuah proses untuk menyesuaikan diri dengan tantangan, mampun menjaga ekuilibrium serta tetap mampu menjaga rasa kontrol terhadap lingkungan serta terus bergerak dalam cara yang positif. Adversity di sisi lain merupakan keadaan menderita atau sulit yang berhubungan dengan ketidakberuntungan, distress, kesulitan atau kejadian tragis (Rutter, 1999; Tugade \& Frederickson, 2004). Adversity dalam dunia kerja dapat digambarkan sebagai sebuah situasi sulit, kondisi negatif, traumatik, penuh tekanan yang dijumpai dalam kehidupan kerja.

\section{PENGGUNAAN KONSEP RESILIENSI}

Penggunaan konstruk resiliensi dalam psikologi banyak berhubungan dengan anak, remaja dan keluarga (Jacelon, 1997; Coleman \& Ganong, 2002). Dalam literature perkembangan anak, resiliensi berhubungan dengan mampu diraihnya dampakdampak menyenangkan dan kepirbadian positif pada anak-anak yang mengalami tekanan hidup.Penelitian awal dilakukan pada anak dengan ibu menderita skizophrenia telah menemukan resiliensi sebagai area penting secara teoritis dan empiris (Luthar, et al, 2000). Penelitian resiliensi anak selanjutnya dilakukan pada area tekanan hidup yang lebih luas seperti kemiskinan, penyakit kronik, kejadian traumatik, serta pengabaian dan abuse pada anak (Luthar, et al, 2000).

Resiliensi pada remaja telah difokuskan pada para remaja yang berisiko terhadap problem-problem psikososial seperti pada remaja di penjara yang berisiko secara ekstrim untuk mengembangkan dampak-dampak negatif secara psikologis.Todis, et al (2001) misalnya mendiskusikan faktor-faktor internal dan eksternal yang membedakan remaja yang pernah menjalani kehidupan di penjara dapat kembali secara berhasil ke komunitas mayarakat.

Konsep resiliensi juga didiskusikan pada konteks mengembangkan kekuatan keluarga (Darbyshire \& Jackson, 2005) dan kemampuan keluarga dalam menghadapi kesulitan (Silberberg, 2001). Patterson (2002) memandang keluarga sebagai sebuah sistem sosial yang dapat resilien dalam cara yang serupa dengan resiliensi individu. Penekanan terletak pada penilaian keluarga secara subjektif terhadap sumbersumber stres keluarga dan kemampuan mereka dalam menanganinya. Terdapat dua perspektif yang 
mendominasi hal tersebut, yaitu adanya paparan kesulitan sebagai prasyarat penting untuk dinilai sebagai resilien, dan usaha pengembangan kekuatan keluarga secara umum dalam menghadapi kehidupan yang penuh tekanan. Joinking (dalam Jackson, et al, 2007) menambahkan perlunya penyediaan layananlayanan dukungan dan pengembangan resiliensi untuk membantu memperkuat individu, keluarga dan komunitas serta meningkatkan kemampuan mereka untuk menolong diri mereka sendiri.Dengan demikian dalam level individual, komunal, keluarga dan institusional, mereka dapat memiliki kerentanan dan sekaligus ketahanan.

Kesadaran akan pentingnya resiliensi di tingkat organisasi maupun staf pekerja dalam institusi telah nampak dalam penelitian mengenai disposisi positif bagi para guru (Gu \& Day, dalam Jackson, et al, 2007), bagi para klinisi kesehatan mental (Edward, 2005) dan bagi para perawat (McGee, 2006). Bright (dalam Jackson, et al, 2004) dan Giordano (1997) menegaskan bahwa membangun resiliensi personal pada seorang perawat berarti mengembangkan kemampuan mereka dalam menangani stres yang berhubungan dengan pekerjaan mereka.Karena itu sebagaimana hasil penelitian bahwa resiliensi dapat dikembangkan untuk menguatkan keluarga (Darbyshire \& Jackson, 2005), resiliensi dapat pula digunakan untuk mengembangkan kekuatan individu maupun kelompok masyarakat termasuk pada para pekerja seperti pada para pendidik dan perawat.

\section{STRATEGI-STRATEGI PENGUATAN RESILIENSI PERSONAL PEKERJA}

Individu dapat mengembangkan dan menguatkan resiliensi personal mereka dengan mengembangkan strategi untuk mengurangi vulnerability atau kerentanan mereka dan pengaruh tekanan-tekanan personal di tempat kerja.Tugade \& Frederickson (2004) menegaskan bahwa tiap orang memiliki potensi resiliensi tetapi levelnya dipengaruhi oleh pengalaman individu, kualitas-kualitas personal, lingkungan dan oleh keseimbangan faktor risiko dan faktor protektif individu. Faktor protektif membantu individu meraih dampak-dampak positif dari risikorisiko atau kesulitan-kesulitan apapun yang mereka hadapi (Tugade \& Frederickson, 2004).

Hasil penelitian membuktikan bahwa sifat kepribadian hardiness membantu melindungi individu dari dampak negatif kejadian-kejadian yang penuh tekanan (Collins, 2006; Judkins, et al, 2005). Hardiness digambarkan oleh Bonanno (2004) memiliki tiga dimensi yaitu adanya komitmen untuk menemukan tujuan hidup, keyakinan bahwa seseorang mampu mempengaruhi sekitarnya dan dampak-dampak tiap kejadian di sekitarnya, serta keyakinan bahwa seseorang mampu belajar dan tumbuh baik dari pengalaman hidup yang positif maupun negatif.

Hasil-hasil penelitian juga membuktikan bahwa hardiness dapat dipelajari.Judkins et al (2005) misalnya menemukan adanya perbedaan sifat hardiness para mahasiswa keperawatan sebelum dan sesudah mereka menempuh program pendidikan administrasi keperawatan. Nilai rata-rata hardiness mereka yang dikuatkan oleh temuan kualitatif menunjukkan perubahan-perubahan penting dalam ketrampilan yang berhubungan dengan tiga elemen hardiness tersebut. Temuan tersebut menguatkan hasil penelitian Bonanno et al (2002) bahwa selfenhancement, koping repressive, emosi positif serta tertawa merupakan hal-hal yang dapat meningkatkan resiliensi.

Tekanan-tekanan dalam berbagai bidang kehidupan dapat memiliki sifat yang khusus sebagaimana misalnya tekanan dalam bekerja. Hasil penelitian Jackson et al (2001) misalnya menemukan sifat dari situasi kerja pada perawat seringkali mencakup tekanan dalam hal kesulitankesulitan interpersonal seperti perasaan terlecehkan, disalahkan atau direndahkan orang lain atau atasan. Problem-problem kerja yang muncul dari problem interpersonal ini dapat memunculkan rasa terluka secara emosi dan dapat mempengaruhi kualitas kerja professional para perawat.Berdasarkan temuan tersebut, Jackson, et al (2007) mengusulkan sejumlah strategi pengembangan diri yang dapat membantu individu dalam meningkatkan resiliensi mereka dalam menghadapi tekanan-tekanan kerja khususnya tekanan yang muncul dari problemproblem interpersonal. Strategi-strategi tersebut adalah :

\section{a. Membangun Jaringan Kerja Dan Relasi Profesional Yang Positif Dan Nurturing}

Dukungan sosial telah diidentifikasi sebagai salah satu faktor penting dalam resiliensi, dan penjagaan hubungan merupakan salah satu komponen dukungan sosial (Tugade \& Frederickson, 2004).Membangun relasi professional yang positif merupakan hal penting dalam dunia kerja.Para pekerja membutuhkan jaringan kerja dari individu-individu yang dapat dimintai dukungan dan nasehat pada saat yang diperlukan.Kolega-kolega kerja ini dapat memberikan penguatan khususnya ketika tekanan-tekanan 
kerja meningkat sangat tinggi dan ketika pekerja mencari dukungan di dalam tempat kerja sebagai akibat adanya situasi kerja yang menghadapkan pekerja pada kerentanan-kerentanannya (Jackson, et al, 2007).

Jaringan kerja professional perlu memasukkan pola-pola relasi yang nurturing, yang menjaga mengayomi, atau dalam istilah Jawa yakni ngemongatau tutwuri handhayani. Menurut Jackson, et al (2007) idealnya semua relasi kolegial perlu memiliki derajat nurturing, tetapi tidak dalam setiap keadaan. Tiap orang kadang memerlukan relasi nurturing semacam itu dalam kondisi-kondisi tertentu. Dalam konteks pekerja perawat misalnya, Daly et al (dalam Jackson, et al, 2007 ) menyatakan bahwa usaha aktif untuk mencari relasi semacam itu seperti dalam relasi mentorship dapat memberikan kesempatan pada para perawat untuk memasuki pola relasi suportif yang menguntungkan. Sebagaimana telah diketahui dalam penelitian resiliensi anak, mentorship juga merupakan pola relasi yang dapat membangun relasi sehat untuk melindungi anak-anak berisiko dan dapat meningkatkan resiliensi mereka (Joinking, 2003).

Aspek kepemimpinan dalam dunia kerja dapat menjadi salah satu faktor penting dalam menyumbangkan pola relasi professional yang positif dan ngemong. Sivanathan, et al (2004) menegaskan pentingnya kepemimpinan transformasional dalam menyumbangkan well-being pekerja. Kepemimpinan transformasional mencakup 4 elemen perilaku yaitu idealized influence, inspirational motivation, intellectual stimulation, dan individualized consideration. Masing-masing dari keempat perilaku kepemimpinan ini memiliki potensi penting bagi peningkatan kesejahteraan pekerja.

Idealized influence mencerminkan perilaku pemimpin yang memilih melakukan sesuatu yang benar daripada sekedar melakukan sesuatu yang dinilai “bijak' atau “layak', sesuatu yang sederhana atau sesuatu yang bernilai efektif. Para pemimpin terlibat dalam perilaku ini karena komitmen moral mereka baik ketika perilaku itu tertuju pada diri mereka sendiri atau pada orang-orang yang dipimpinnya. Para pekerja akan memberikan rasa hormat karena para pemimpin mereka melakukan hal yang benar sehingga manifestasi dari Idealized influence adalah tingginya tingkat kepercayaan para pekerja, juga rasa menghargai dan adanya persepsi positif akan keadilan interpersonal (Turner, et al dalam Sivanathan, et al, 2004).

Inspirational motivation ditampakkan oleh seorang pemimpin ketika menginspirasi para pengikutnya untuk menjadi yang terbaik. Inspirational motivation tidak mengharuskan pemimpin untuk memiliki perilaku kharismatik yang bersifat khusus tetapi bagaimana seorang pemimpin mampu meyakinkan pengikutnya atau para pekerja bahwa mereka mampu menembus hambatan-hambatan baik secara internal diri maupun secara eksternal. Pemimpin juga mampu menanamkan rasa efikasi diri yang realistic, serta perasaan untuk mampu menyelesaikan apa yang bisa diselesaikan daripada mencemaskan apa yang tidak bisa diselesaikan. Pesan-pesan positif seringkali disampaikan melalui penggunaan simbol-simbol atau cerita.

Intellectual stimulation digunakan oleh para pemimpin tidak dengan cara memberikan jawabanjawaban bagi pekerjanya. Mereka menantang pekerja untuk bisa berpikir lebih dan secara kontinyu menanyakan dan menghargai asumsi-asumsi mereka. Hal ini penting dalam meningkatkan kesejahteraan pekerja karena para pekerja menjadi lebih percaya diri dan lebih meningkat rasa efikasi dirinya.

Individualized consideration sebagai komponen perilaku kepemimpinan transformasional merefleksikan perilaku pemimpin yang menunjukkan perhatian terhadap perkembangan para pekerja serta keselamatan fisik-psikis mereka. Mereka melakukannya dengan cara mendengarkan, peduli, memperhatikan, serta berempati khususnya selama masa-masa sulit ketika para pekerja sedang sangat membutuhkannya. Melalui komponen inilah para pemimpin mengembangkan dan merekatkan para pekerja.

\section{b. Menjaga Positifitas}

Kesulitan-kesulitan hidup bukan merupakan fenomena positif tetapi kesulitan dan tekanan seringkali memiliki sisi-sisi positif.Individu yang resilien mampu mengambil sejumlah bentuk emosi positif bahkan di tengah-tengah kesulitan dan tekanan (Tugade \& Frederickson, 2004; Frederickson, 2004). Optimisme dan mampu melihat kemungkinankemungkinan ke depan merupakan aspek penting untuk menjaga pandangan positif (Brgiht, dalam Jackson, et al, 2007). Individu yang resilien mampu melihat aspek positif dan keuntungan-keuntungan potensial dari sebuah situasi daripada bersikap negatif.Emosi positif dan humor merupakan dua hal yang berdampak positif bagi kesehatan dan emosi (Tugade \& Frederickson, 2004). Bonanno (2004) juga menegaskan bahwa emosi positif dan humor dapat mengurangi tingkat stres sebagai dampak tekanan dengan mengurangi tingkat emosi negatifnya. 
Bersyukur merupakan salah satu cara untuk memunculkan emosi positif sebagaimana penelitian Watkins (dalam Bono, et al, 2004). Pada para partisipan yang diminta berpikir dan menuliskan rasa terimakasih mereka pada seseorang yang mereka merasa sangat berterimakasih ternyata menunjukkan emosi positif yang sangat kuat. Hasil penelitian tersebut sejalan dengan Frederickson (2004) bahwa pengalaman emosi positif dapat memperluas perhatian dan kognisi individu sehingga dapat memperbaiki kemampuan koping dan pemfungsian diri secara optimal.

\section{c. Mengembangkan Insight Emosi}

Pentingnya kecerdasan emosi atau emotional intelligence (EI) telah banyak memperoleh perhatian termasuk dalam dunia kerja.Kecerdasan emosi merupakan kemampuan untuk memahami kebutuhankebutuhan emosi diri sendiri, dan memiliki insight untuk kebutuhan emosi yang dijumpai dalam dunia kerja (Daly, et al, 2004). Memahami kebutuhankebutuhan dan reaksi-reaksi emosi diri sendiri dapat memberikan insight-insight tentang bagaimana mengatasi stres dan tekanan serta membantu memunculkan ide-ide mengenai beragam cara pengatasan stres di masa mendatang (Bright, dalam Jackson, et al, 2007). Selain itu sebagaimana telah dituliskan sebelumnya emosi positif dapat membantu pengembangan resiliensi (Tugade \& Frederickson, 2004) sehingga mengembangkan insight terhadap emosi positif dan negatif juga dapat menjadi langkah pertama untuk memperkuat resiliensi personal. Giordano (dalam Jackson, et al, 2007) menekankan pentingnya menulis jurnal/catatan harian dan refleksi diri sebagai cara meningkatkan insight emosi.

\section{d. Meraih Keseimbangan Hidup Dan Spiritualitas}

Sejumlah penulis menggambarkan pentingnya perasaan keterhubungan atau connectedness, meraih keseimbangan hidup dan memiliki "anchoring force" dalam kehidupan (Giordano dalam Jackson, et al, 2007).

\section{DAFTAR PUSTAKA}

Bonanno G. (2004) Loss, trauma and human resilience: have we underestimated the human capacity to thrive after extremely aversive events? American Psychologist 59, 20-28.

Bono, G., Emmons, R. \& McCullough.(2004)
Tusaie \& Frederickson (2004) mengakui pentingnya sebuah sistem keyakinan yang menyediakan makna eksistensial dan apresiasi mengenai keunikan diri untuk memiliki tingkat resiliensi yang tinggi.Disamping keyakinan-keyakinan spiritual, berpartisipasi dalam aktivitas-aktivitas menyehatkan diluar kegiatan professional dapat menjadi hal yang penting seperti aktivitas yang dapat menunjang secara fisik, emosi dan spiritual.

e. Menjadi Lebih Reflektif.

Refleksi merupakan salah satu cara untuk mengembangkan insight-insight dan pemahamanpemahaman terhadap pengalaman maupun pengetahuan yang digunakan dalam situasi-situasi penting. Dalam refleksi pengalaman kongkrit digunakan sebagai katalisator berpikir dan belajar.Menulis buku harian dapat merupakan strategi reflektif berharga (Giordano dalam Jackson, et al, 2007). Jackson juga menegaskan menulis pengalaman menjadi hal berharga karena penulisnya dapat menggambarkan makna kejadian. Karena itu pemahaman-pemahaman dan insightinsight baru dapat muncul melalui tindakan menulis. Misalnya ketika seseorang mengalami emosi-emosi negatif secara konsisten terhadap seseorang, suatu tempat atau suatu keadaan maka menuliskannya dapat menjadi langkah yang bisa memperjelas masalah dan menjadi katalisator untuk merefleksi dan mengekeplorasi cara-cara memilih respon yang lebih positif terhadap orang, situasi ataupun keadaan (Jackson, et al, 2007).

\section{KESIMPULAN}

Resiliensi dalam kehidupan kerja merupakan hal yang bisa untuk terus diusahakan. Tidak hanya berfokus pada kekuatan-kekuatan internal individu tetapi optimalisasi peran eksternal terutama kepemimpinan dan jaringan dukungan sosial dari rekan sekerja menjadi aspek-aspek penting yang membantu individu untuk resilien. Resiliensi pekerja memberikan manfaat bagi inidvidu pekerja dalam hal peningkatan kesejahteraan psikologis serta kebermaknaan hidup dan dimungkinkan dapat berpengaruh pada produktivitas kerja mereka.

Gratitude in practice and practice of gratitude. In Linley.A. \& Joseph, S. (editors) Positive psychology in practice. New Jersey, Canada. John Wiley \& Sons, Inc, pp 464-481.

Cline D., Reilly C. \& Moore J. (2003) What's behind RN turnover? Uncover the 'real reasons' nurses leave. Nursing Management 34,10-53. 
Collins M.C. (1996) The relation of work stress, hardiness, and burnout among full-time hospital staff nurses. Journal of Nurse Staff Development 12, 81-85.

Coleman M. \& Ganong L. (2002) Resilience and families.Family Relations 51, 101.

Darbyshire P. \& Jackson D. (2005) Using a strengths approach tounderstand resilience and build health capacity in families. Contemporary Nurse 18, 211-212.

Edward K. (2005) The phenomenon of resilience in crisis care mental health clinicians. International Journal of Mental Health Nursing 14, 142-148.

Fredrickson B. (2004) The broaden-and-build theory of positive emotions. Philosophical Transactions of the Royal Society London B Biological Sciences 359, 1367-1377.

Giordano B. (1997) Resilience: a survival tool for the nineties. Association of Perioperative Registered Nurses Journal 65, 1032-1036.

Judkins S., Arris L. \& Keener E. (2005) Program evaluation in graduate nursing education: hardiness as a predictor of success among nursing administration students. Journal of Professional Nursing 21, 314-321.

Luthar S., Cicchetti D. \& Becker B. (2000) The construct of resilience: a critical evaluation and guidelines for future work. Child Development 71, 543-562.

McGee E. (2006) The healing circle: resiliency in nurses. Issues in Mental Health Nursing 27, 43-57.

McVicar A. (2003) Workplace stress in nursing: a literature review. Journal of Advanced Nursing 44, 633-642.

Patterson J. (2002) Understanding family resilience.Journal of Clinical Psychology 58, 233-246.
Rabkin J., Remien R., Katoff L. \& Williams J. (1993) Resilience in adversity among long term survivors of AIDS. Hospital and Community Psychiatry 44, 193-200

Rutter M. (1999) Resilience concepts and findings: implications for family therapy.Journal of Family Therapy 21, 119-144.

Sasongko, Dwiwahju, (2013), Penjaminan Mutu, Akreditasi, dan Tata Kelola Pendidikan Tinggi, Makalah Kolokium Psikologi Indonesia XXII, Asosiasi Penyelenggara Pendidikan Tinggi Psikologi Indonesia, Bandung, April

Sivanathan, N., Arnold, K.A., Turner, N., and Barling, J. (2004) Leading well: transformational leadership and well-being. In Linley.A. \& Joseph, S. (editors) Positive psychology in practice. New Jersey, Canada. John Wiley \& Sons, Inc, pp 241-255

Silberberg S. (2001) Searching for family resilience. Family Matters 58, 52-57.

Tusaie K. \& Dyer J. (2004) Resilience: a historical review of the construct. Holistic Nursing Practice 18, 3-10.

Tugade M. \& Fredrickson B. (2004) Resilient individuals use emotions to bounce back from negative emotional experiences. Journal of Personality and Social Psychology 86, 320-333.

Todis B., Bullis M., Waintrup M., Schultz R. \& D'Ambrosio R. (2001) Overcoming the odds: qualitative examinations of resilience among formerly incarcerated adolescents. Exceptional Children 68, 119-139.

Yahaya, Noordin and Jaalam, Saini and Yahaya , Azizi (2009) Faktor-faktor yang mempengaruhi stres di kalangan guru sekolah menengah / Noordin Yahaya, Saini Jaalam and Prof. Madya Dr. Azizi Hj. Yahaya.Technical Report. Institute of Research, Development and Commercialization , Universiti Teknologi MARA. (Submitted) - http://eprints.uitm. edu.my/2213/diunduh tanggal 29-9-2013 